\title{
PHIALOPTERIS HETEROPHYLLA (STERNBERG EX GÖPPERT, 1836) COMB. NOV., A RARE SCHIZAEACEOUS FERN FROM THE EARLY JURASSIC OF BAVARIA
}

\author{
JOHANNA H. A. VAN KONIJNENBURG-VAN CITTERT ${ }^{1, *}$, CHRISTIAN POTT ${ }^{2}$, EVELYN KUSTATSCHER ${ }^{3,4,5}$, \\ STEFAN SCHMEISSNER ${ }^{6}$, GÜNTER DÜTSCH${ }^{7}$, JOHAN VAN DER BURGH ${ }^{1}$
}

\author{
1 Laboratory of Palaeobotany and Palynology, Princetonlaan 8A, 3584 CB Utrecht, The Netherlands; e-mail: j.h.a.vankonijnenburg@uu.nl, \\ j.vanderburgh@uu.nl. \\ 2 LWL-Museum of Natural History, Westphalian State Museum with Planetarium, Sentruper Straße 285, D-48161 Münster, Germany; e-mail: \\ christian.pott@lwl.org. \\ ${ }^{3}$ Museum of Nature South Tyrol, Bindergasse/via Bottai 1, 39100 Bozen/Bolzano, Italy; e-mail: evelyn.kustatscher@naturmuseum.it. \\ ${ }^{4}$ Department für Geo- und Umweltwissenschaften, Paläontologie und Geobiologie, Ludwig-Maximilians-Universität, Theresienstraße 41, \\ 80539 Munich, Germany. \\ ${ }^{5}$ Bayerische Staatssammlung für Paläontologie und Geologie, Richard-Wagner-Straße 10, 80333 Munich, Germany. \\ ${ }^{6}$ Matthäus-Schneider-Straße 14, D-95326 Kulmbach, Germany. \\ 7 Eichbergstraße 25a, D-95369 Untersteinach, Germany. \\ *corresponding author
}

Van Konijnenburg-van Cittert, J. H. A., Pott, C., Kustatscher, E., Schmeissner, S., Dütsch, G., Van der Burgh, J. (2018): Phialopteris heterophylla (STERNBERG ex GÖPPERT, 1836) comb. nov., a rare schizaeaceous fern from the Early Jurassic of Bavaria. Fossil Imprint, 74(1-2): 55-64, Praha. ISSN 2533-4050 (print), ISSN 2533-4069 (on-line).

\begin{abstract}
Recently collected material of the monotypic schizaeaceous fern genus Phialopteris is described including for the first time the in situ spores. The complex nomenclatural history of the type species is discussed, resulting in the designation of the new combination Phialopteris heterophylla (STERnBerg ex GöPpert, 1836) comb. nov. as type. This delicate fern has so far only been found in the Hettangian of Bavaria (Germany). Along with a comparison with contemporary schizaeaceous ferns and extant members of Schizaeaceae, and with dispersed spores, the possibility that this fern might have been a climbing fern, similar to some living Lygodium species, is briefly discussed.
\end{abstract}

Key words: Schizaeaceae, Hettangian, Germany, Lygodium, climbing fern, growth habit

Received: November 21, 2017 | Accepted: January 24, 2018 | Issued: August 31, 2018

\section{Introduction}

The monotypic schizaeaceous genus Phialopteris C.Presl in Sternberg, 1838 constitutes rare fossil plants that have been found so far only in Early Jurassic (Hettangian) sediments in Bavaria. Over time, various names have been used for specimens of its type species such as Asterocarpus heterophyllus Sternberg, Phialopteris tenera C.PresL or Norimbergia braunii (GöPPERT) Gothan. One of the aims of this paper is to clarify the nomenclature of this fossil plant. Only a limited number of fossils of both sterile and fertile specimens have been described from a small number of localities in Bavaria (Göppert 1836, Sternberg 1838, Gothan 1914, Kräusel 1958, Weber 1968), but details of the sporangia morphology as well as in situ spores were so far unknown. However, during recent years, several new Phialopteris specimens were recovered from lately explored sand pits in Bavaria. One of these specimens also yielded in situ spores. We here describe and illustrate the new material, which adds considerably to our knowledge of Phialopteris.

\section{Material and methods}

The type of Phialopteris comes from Reundorf near Bamberg (Text-fig. 1; Göppert 1836, Schenk 1864, Jung and Knobloch 1972), a locality that was formerly considered to be Late Triassic in age, but nowadays, a Hettangian age has been assigned to it (see Freudenberger 1994). Sternberg (1838) originally called the locality Steindorf, but previously Göppert (1836) used the name Rheindorf for the locality and Schenk (1864) mentioned the Rhaetian Formation from Reindorf, Höfen und Strullendorf near Bamberg. Sternberg (1838) most likely misinterpreted the handwriting on the specimen label. Jung and Knobloch (1972: 107) recognised that the locality must be Reundorf, and not Steindorf or R(h)eindorf, and as proof illustrated the original label of the type specimen. 


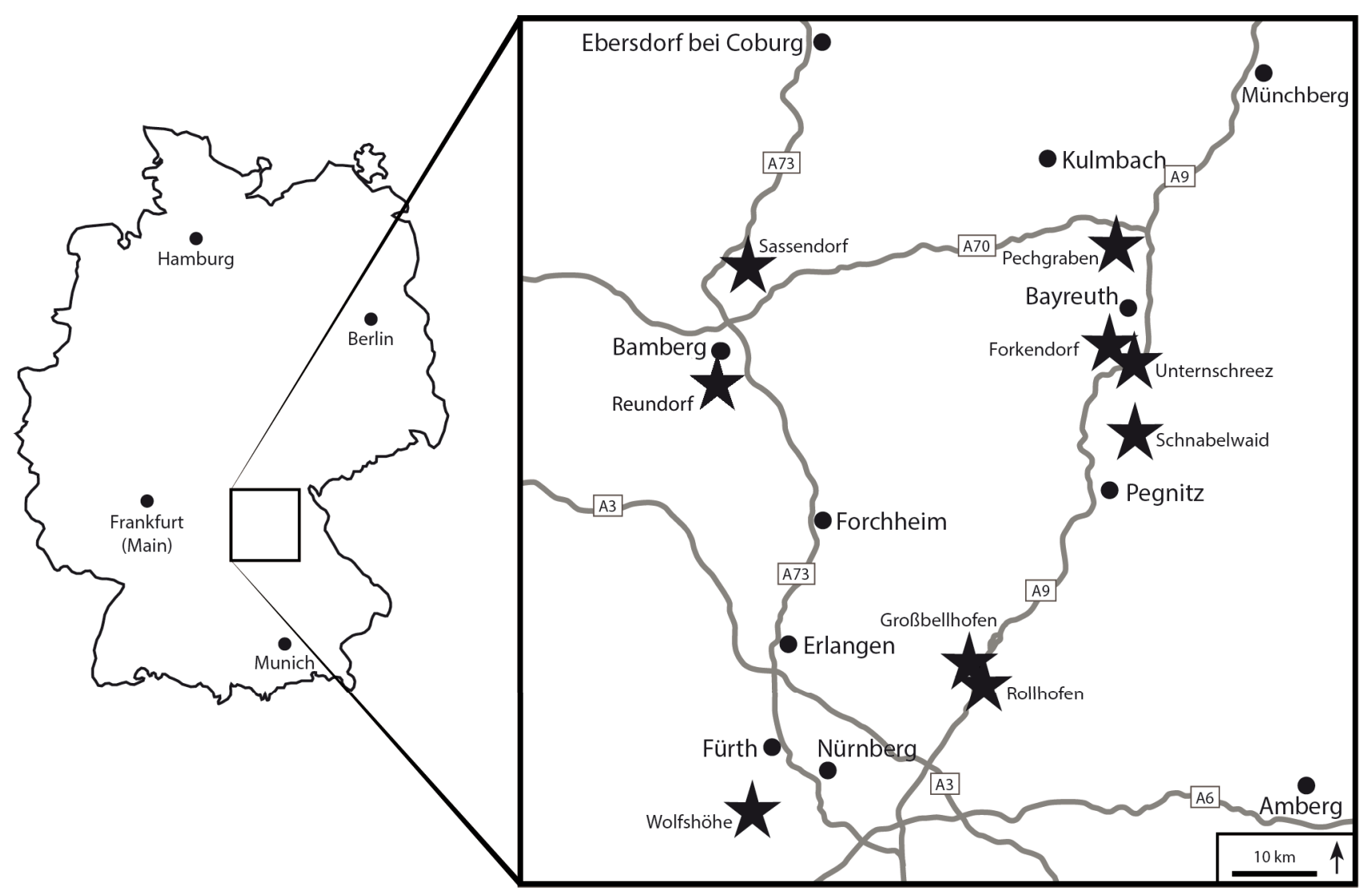

Text-fig. 1. Map indicating the localities where Phialopteris heterophylla has been found.

Kräusel (1958) recorded the species from the Hettangian flora of Sassendorf near Bamberg, Gothan (1914) mentioned material from Rollhofen near Nuremberg, and Weber (1968) recorded several specimens from Grossbellhofen, Wolfshöhe (both near Nuremberg), and Unternschreez, sandpit Pross, and Schnabelwaid (both south of Bayreuth). Hettangian sediments crop out in all these localities, just as in the areas where the new specimens were recently collected, such as from Unternschreez sandpit Lautner, Pechgraben sandpits Küfner and Dietz, and Forkendorf near Bayreuth (Text-fig. 1).

Most of the specimens are preserved in coarse sandstone (Weber 1968) and thus do not reveal much more than their gross-morphology, but material from some of the localities (e.g. Unternschreez sandpit Lautner, Pechgraben sandpits Küfner and Dietz) was found in lenses of finer-grained clay within the sand pits. Those were better preserved and yielded more details, including in situ spores.

Specimens stored in the collection of the Laboratory of Palaeobotany and Palynology, Utrecht (The Netherlands) have the prefix "UU". Specimens from the private collection of Stefan Schmeissner (Kulmbach, Germany) have the prefix "E" (sandpit Dietz) and "G" (sandpit Küfner) and those collected by Günter Dütsch (Untersteinach, Germany) have "D" (sandpit Dietz) and "Kü" (sandpit Küfner) in the middle of the identification numbers.

The material was studied under a dissecting microscope and photos were taken with a Nikon D750/Nikkor AF-S Mikro $60 \mathrm{~mm}$ f/2.8G ED system digital camera, fitted with polarizing filter in front of the camera lens, and also with a Panasonic Lumix DMC-FZ1000 with a Leica DC Vario-Elmarit lens. The in situ spores were prepared by picking sporangia directly from the rock surface. They were macerated using Schulze's reagent $\left(30 \% \mathrm{HNO}_{3}\right.$ with a few crystals of $\mathrm{KClO}_{3}$ ) and subsequently treated with 5-10\% ammonia $\left(\mathrm{NH}_{4} \mathrm{OH}\right)$. Macerated sporangia were rinsed with water. The spores were then separated with the aid of needles, embedded in glycerine jelly and sealed with paraplast. The slides are stored in the collection of the Laboratory of Palaeobotany and Palynology. The spores were studied under an Olympus BH2 light microscope (LM) and a Camscan scanning electron microscope (SEM).

\section{Nomenclature}

The nomenclature of Phialopteris C.PRESL in STERNBERG, 1838 has become more complex over the years (see Jung and Knobloch 1972). Göppert (1836) described Asterocarpus heterophyllus STERNBERG based on illustrations that Sternberg presented to him two years before the publication of part 7 and 8 of the $2^{\text {nd }}$ volume of the "Flora der Vorwelt" (Sternberg 1838: pl. 32, fig. 1). Göppert (1836) gave a definite species diagnosis and assigned the species provisionally to the Gleicheniaceae. For the illustrations, Göppert referred to pl. 32, fig. 1a-d of Sternberg (1838), although quoting pl. 31 instead of pl. 32 probably by mistake according to a note by Presl in Sternberg (1838). Upon publication, Presl introduced the new generic name Phialopteris in Sternberg (1838), based on the same specimens as Göppert (1836), with Phialopteris 
tenera C.Presl in SternBerg, 1838 as its only species. Presl placed the older name Asterocarpus heterophyllus GöPPERT (1836: 382) in the synonymy. According to nomenclatorial rules (McNeill et al. 2012: Art. 11.4), Phialopteris tenera is consequently illegitimate, although the generic name Phialopteris was validly and legitimately published; the correct name of the type species is Phialopteris heterophylla (STERnBerg ex GöPPERT, 1836) comb. nov.

New names of fossil plants and other nomenclatural acts are being registered in the Plant Fossil Names Registry, which is hosted and operated by the National Museum, Prague for the International Organisation of Palaeobotany (IOP), each with a unique registry number.

Kräusel (1958) correctly attributed the authority of the name Asterocarpus heterophyllus not to Sternberg (as Göppert stated) but to Göppert (1836) himself. Kräusel's (1958) statement that Göppert did not provide a description is incorrect (Göppert 1836: 382-383). Here, Göppert referred to Sternberg's illustrations and definitely gave a short description and a brief discussion of the species including a preliminary attribution to the Gleicheniaceae. Kräusel (1958) also assigned Norimbergia GotHan to the synonymy of Phialopteris. Gothan (1914) based Norimbergia on Sphenopteris braunii GÖPPERT, 1841, proposing the new combination Norimbergia braunii (GÖPPERT) GoTHAN, 1914. Gothan (1914) discussed the similarity with Phialopteris tenera (agreeing with the priority of Asterocarpus heterophyllus), and placed both species names provisionally in the synonymy of Norimbergia braunii, supposing that Norimbergia braunii and Phialopteris tenera correspond to the same species. We here agree with Kräusel (1958) that the two species are congeneric and that Norimbergia is a junior synonym of Phialopteris, but we conclude that the species Norimbergia braunii also falls within the synonymy of Asterocarpus heterophyllus/Phialopteris tenera. Kvaček and Straková (1997: 38) in their catalogue of Sternberg's type specimens also concluded that the name Asterocarpus heterophyllus had priority over Phialopteris tenera, but they suggested including the latter name in the list of conserved names. However, the name Phialopteris tenera has only been used in a small number of publications, and the species is very limited in time and space. Therefore, the name Phialopteris tenera would not qualify for conservation (Gea Zijlstra, pers. comm., November 2017).

The specimens of Asterocarpus heterophyllus/Phialopteris tenera cannot be assigned to Asterocarpus or Asterotheca (see Pott et al. (2018) on the nomenclatorial issues of Asterocarpus/Asterotheca) due to the nature of the single sporangia. Therefore, the species is assigned here to Phialopteris as Phialopteris heterophylla (STERnBerg ex GÖPPERT) comb. nov. Further evidence for this assignment is provided in the present study based on newly collected material. The material also allows us to clarify the higher taxonomic position of the genus and species.

\section{Systematic palaeobotany}

\author{
Class Polypodiopsida Cronquist, TakHTajan et \\ W.ZIMMERMAN, 1966 \\ Order Schizaeales Schimper, 1869 \\ Family Schizaeaceae KaUlfuSs, 1827
}

Genus Phialopteris C.Presl in Sternberg, 1838

Phialopteris heterophylla (STERnBERG ex GöPPERT)

Van Konijnenburg-van Cittert, Pott, Kustatscher, Schmeissner, Dütsch et Van der Burgh, comb. nov. Pls 1-3, Text-fig. 2

B a sionym. Asterocarpus heterophyllus GöPPERT, 1836, Die fossilen Farnkräuter, p. 382.

1836 Asterocarpus heterophyllus GÖPPERT, p. 382.

1838 Phialopteris tenera C.PresL in Sternberg, p. 114, pl. 31, figs 1a-6.

1841 Sphenopteris braunii GöPPERT, p. 69, pl. 10, figs 1, 2.

1867 Coniopteris braunii (GöPPERT) SCHENK, p. 36, pl. 6, figs 6-8.

1914 Norimbergia brauni (GöPPERT) GOTHAN, p. 107, pl. 18, figs 6-8.

1958 Phialopteris tenera C.PresL in Sternberg; Kräusel, p. 70, pl. 3, fig. 8 .

1968 Phialopteris tenera C.PresL in STERnBerG; Weber, p. 45, pl. 4, figs 43-45, pl. 5, figs 46-49.

1972 Phialopteris tenera C.PresL in SternBerg; Jung and Knobloch, p. 107, text-fig. 1.

1997 Phialopteris tenera C.PresL in Sternberg; Kvaček and Straková, pp. 20, 83.

Lect otype. Designated here. BT 760, Geological Museum of Bayreuth, figured in Sternberg (1838: 114, pl. 31, fig. 1al). Counterpart - Bayerische Staatssammlung für Paläontologie und Geologie, Munich, SNSB-BSPG AS VII 402.

Plant Fossil Names Registry Number. PFN000109 for new combination; PFN000120 for lectotype designation.

Type locality. Reundorf near Bamberg, Bavaria, Germany.

Type horizon and age. Hettangian, lower Jurassic.

Material described. UU10015, UU10749, UU10849, UU10960, UU11015 (all from sandpit Lautner, Unternschreez), UU11932, UU11933; 30Kü16, 37Kü16, 38Kü16, G1164-16 (sandpit Küfner, Pechgraben); 23D02, 24D02, E15-91, E215-93 (sandpit Dietz, Pechgraben); UU25755 (Forkendorf).

Description. Phialopteris heterophylla is a delicate fern. Many specimens yield partly or entirely fertile frond portions, only a few sterile portions have been found on some slabs so far. All specimens are incomplete. The fronds are tripinnate, with a thin rachis, up to $500 \mu \mathrm{m}$ wide, sometimes showing a zig-zag-shape (Pl. 1, Figs 1, 2; Pl. 2, Fig. 5; Pl. 3, Fig. 2). The primary pinnae arise at $30-55^{\circ}$ depending on their position in the frond, are alternately or suboppositely arranged, and up to $70 \mathrm{~mm}$ long. Secondary pinnae are up to $25 \mathrm{~mm}$ long but usually shorter, while ultimate pinnules are up to $10 \mathrm{~mm}$ long and $2 \mathrm{~mm}$ wide. The branching is commonly katadromic, but the first anadromic ultimate pinnule is often enlarged (Pl. 1, Figs 1, 2; P1. 2, Fig. 3). A clear midrib is visible in the ultimate pinnules; secondary venation is commonly invisible, which might be due to the delicate nature of the lamina.

Entirely sterile frond portions in the new material are only preserved on specimens UU11933 and 37Kü16. The 

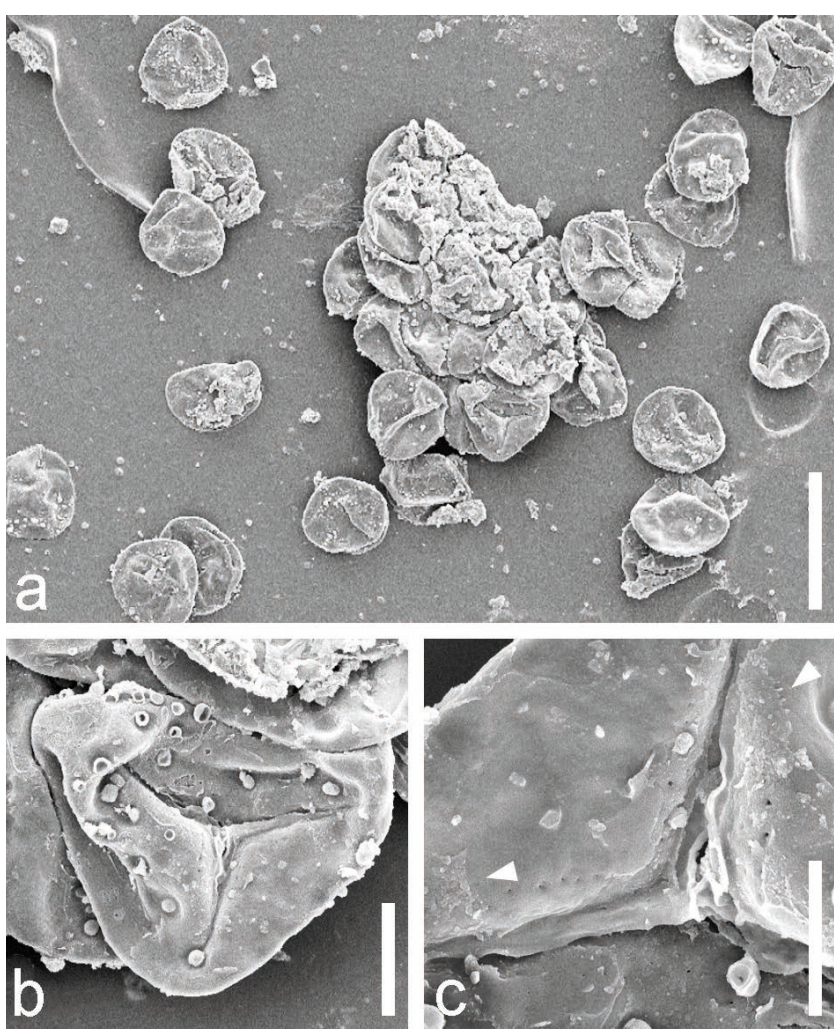

Text-fig. 2. Spores of Phialopteris heterophylla (SEM). a) group of spores from one sporangium, b) trilete spore showing general morphology, and c) detail of (b) showing smooth endospore and faintly granulate perispore remains (arrowheads). Scale bar: a) $50 \mu \mathrm{m}$, b) $20 \mu \mathrm{m}$, c) $10 \mu \mathrm{m}$.

first (Pl. 1, Figs 1, 2) is an apical frond fragment $(62 \mathrm{~mm}$ long and $20 \mathrm{~mm}$ wide) with loosely arranged primary pinnae. The secondary pinnae are ca. $10 \mathrm{~mm}$ long, the ultimate pinnules up to $2 \mathrm{~mm}$ long. The second specimen (Pl. 2, Fig. 5) provides more densely arranged pinnae, of which the secondary pinnae are up to $11 \mathrm{~mm}$ long and the ultimate pinnules up to $2.5 \mathrm{~mm}$ long.

Frond portions that yield both sterile and fertile pinnules are preserved on 30Kü16 and G1164-16. The proximal ultimate pinnules are commonly sterile and up to $3 \mathrm{~mm}$ long and $2.5 \mathrm{~mm}$ wide, while the distal and apical ultimate pinnules are partly (30Kü16; Pl. 2, Fig. 3) or entirely (G1164-16; Pl. 3, Fig. 2) fertile. The specimen E215-93 (Pl. 3, Fig. 1) shows sterile frond portions on the left side of the slab, and fertile pinnules on the right side. The two parts are not organically connected but are embedded in one plane, so they may have been part of the same dimorphic frond in which proximal primary pinnae appear to be sterile and distal ones fertile. Other specimens yield (almost) entirely fertile frond portions. A 65 -mm-long and 40-mm-wide frond fragment is preserved on UU11015 (Pl. 2, Fig. 1); it has up to six secondary pinnae. The ultimate pinnules (fertile "spikes") are up to $10 \mathrm{~mm}$ long (commonly only 6-7 $\mathrm{mm}$ ) and have a dentate lamina margin with two rows of alternately arranged sporangia attached to the abaxial surface. The sporangia are circular to slightly oval in shape and have a diameter of ca. $700 \mu \mathrm{m}$. The first acroscopic ultimate pinnules appear to be divided into two (or three) lobes ("spikes"). Further details of the sporangia are, unfortunately, obscured by the preservational condition of the specimen. Fertile spikes vary in length from 4 to $6 \mathrm{~mm}$ on E215-93. The number of sporangia is clearly visible in this specimen; it varies between 12 to 20 sporangia per fertile spike (pinnule) here.

All completely preserved fertile secondary pinnae end in an apical spike-like ultimate pinnule that is usually larger (longer?) than the other ultimate pinnules (Pl. 2, Fig. 1). The specimens 23D02 and 24D02 yield bipinnate frond fragments and clearly show the arrangement of the fertile spikes mentioned above: In 23D02 (Pl. 2, Fig. 2), some ten fertile secondary pinnae with spikes arise at an angle of ca. $80^{\circ}$; 24D02 (Pl. 2, Fig. 4) provides the densest frond portions with a large number of spikes with preserved sporangia.

Several sporangia were macerated; they yielded large clusters of immature, often slightly folded, spores (Pl. 3, Fig. 5; Text-fig. 2a). The trilete spores (Pl. 3, Figs 3, 4; Textfig. $2 \mathrm{~b})$ are large $(55-70 \mu \mathrm{m}$ in diameter) and roundish triangular in outline. The exospore is smooth; in a few spores, traces of a faintly granulate perispore were observed (Text-fig. 2b, c).

R e marks. Phialopteris heterophylla has a restricted geographical and stratigraphical range as it is known only from a few Hettangian localities in southern Germany. The new material collected from various localities in Bavaria is identical with the specimens described by Presl in Sternberg (1838), Schenk (1864), Gothan (1914), Kräusel (1958) and Weber (1968), and thus can confidently be identified with the species. All published specimens are also only small frond fragments, none of them longer than $60 \mathrm{~mm}$. Most show a bi- or tripinnate frond architecture and all show the typical thin, zig-zag-shaped rachis. The specimen illustrated by Kräusel (1958) yields a sterile frond fragment, but all other published material shows fertile material only, some of which are dimorphic with sterile portions. Gothan (1914: pl. 18 , fig. 8) illustrated the arrangement of the sporangia on the dentate lamina of the fertile spikes, also indicating an apical annulus. In the present material, details of an annulus were not observed, but the sporangium is identical in all other aspects. However, we could recover in situ spores of this species for the first time, although they are not completely mature.

\section{Attribution to the Schizaeaceae and comparison with other coeval fossils}

Based on its sporangial morphology, Phialopteris heterophylla is attributed to the Schizaeaceae. The single, large sporangia are arranged in two rows in "spikes" (or "sorophores" of some authors; e.g. Gandolfo et al. 2000), which is a characteristic feature of Schizaeaceae and encountered in several schizaeaceous genera, both fossil and extant. The family has a long evolutionary history; it has been recorded from possibly the late Carboniferous onwards, but undoubtedly from the Late Triassic (Van Konijnenburgvan Cittert 1991, 1992, Axsmith 2009, Pott et al. 2018).

A very similar schizaeaceous fern is Stachypteris spicans Pomel, 1849, reported from the Middle - Late Jurassic of, e.g. France and the UK, which is also a small fern but apparently not as delicate as Phialopteris heterophylla (Pomel 1849, Harris 1961). Its gross-morphology is similar with sporangia 
arranged in two rows in fertile spikes. The branching of the fronds is katadromic as well, but the first ultimate anadromic pinnule is not enlarged. In contrast to $P$. heterophylla, the sporangia in the fertile spikes of $S$. spicans are clearly oval as opposed to round, 500-600 $\mu \mathrm{m}$ long and $300 \mu \mathrm{m}$ wide (Harris 1961). In situ spores of $S$. spicans are also trilete, but have very distinct sculpture, being distally coarsely reticulate and proximally granulate (Van Konijnenburg-van Cittert 1991, 1992), in contrast to the almost smooth spores of $P$. heterophylla.

Spesia antarctica OCIEPA et BARBACKA, 2011 from the Middle Jurassic of Hope Bay, Antarctica, is another fern that is remarkably similar (Ociepa and Barbacka 2011). The known fertile frond fragments consist of ca. 2-mm-long spikes terminally arranged on ultimate axes. The spikes consist of 2 (rarely 4) rows of sporangia. No lamina has been discerned so far. The sporangia are circular and ca. $300 \mu \mathrm{m}$ in diameter. In situ spores have not been reported.

\section{Comparison with extant Schizaeaceae, possible growth habit and ecological interpretation of Phialopteris heterophylla}

Living Schizaeaceae comprise five genera, Anemia O.Swartz, 1806 and Mohria O.Swartz, 1806 (subfamily Anemioideae), Schizaea J.E.SмIтн, 1793 and Actinostachys WALLICH, 1829 (subfamily Schizaeoideae), and Lygodium O.SwARTz, 1800 (subfamily Lygodioideae) (Christenhusz et al. 2011). Of those, Lygodium is the most similar to Phialopteris with its marginal and terminal sorophores or fertile spikes; Anemia and Mohria differ because they have fully sterile and fully fertile fronds, Schizaea and Actinostachys have blade-like, often filiform, sterile and fertile fronds, the fertile fronds with a small, pinnate fertile segment at its apex. Some authors divided Lygodium into three subgenera (Gisopteris BERNHARDI, 1800, Odontopteris BERNHARDI, 1800 and Lygodium s. str.), of which Lygodium s. str. is the most similar to Phialopteris, with some species that are remarkably similar to the fossil $P$. tenera, e.g. Lygodium flexuosum (L.) O.SwarTz, 1800 and L. japonicum (Thunberg) O.Swartz, 1800. Both species have a relatively thin rachis often exhibiting a zig-zag-shape.

Interestingly, both are so-called "climbing ferns". Their fronds have almost unlimited growth, climbing through forests (see e.g. De la Sota and Morbelli 1987, Rozefelds et al. 2017). Whether Phialopteris heterophylla could be interpreted as a climbing fern is uncertain. Typical features characterising some climbing seed ferns, such as tendrils or holdfasts, are not present (cf. Krings and Kerp 1999), but extant climbing Lygodium species do not have such adaptations either. The thin rachis of their fronds simply twines around supports. The zig-zag-shaped, very thin and flexible rachis of Phialopteris heterophylla could possibly indicate a similar climbing mechanism for this species (e.g. P1. 1, Figs 1, 2; and also Weber 1968: figs 45, 48).

Phialopteris heterophylla was probably growing in a "lowland" habitat with vegetation in relatively moist environments. All localities in which the species has been found so far have yielded a diverse array of plants with a large number of different fern species, especially Todites princeps (Weber 1968) but also a reasonable number of gymnosperms (Pachypteris, Podozamites, see e.g. Gothan 1914, Kräusel 1958, Weber 1968). In all those floras, Phialopteris heterophylla is a rare element, constituting $1-5 \%$ of the specimens (apart from Reundorf for which no data are available). The majority of the specimens have been found in small clay lenses in (old) sandpits, indicating that the species probably grew along small fresh-water streams. Some of those clay lenses contain a large number of species, others (like the one in which G1164-16 was found) only a few. Weber (1968) interpreted the plants as being able to quickly colonize clay soils that fell dry for short periods.

Most specimens of $P$. heterophylla are not associated with other taxa on the slabs, but that might be due to the relatively small size of the slabs or the absence of data. Only two of our specimens contained other taxa, i.e., the presence of Podozamites distans (C.PresL) BrAUN, 1843 leaves in material from Pechgraben sandpit Küfner and Matonia braunii (GöPPERT) HARRIS, 1980 in the Forkendorf specimen. Weber (1968) mentioned a close association of $P$. heterophylla with Todites princeps (C.PRESL) Gothan, 1838 in a number of specimens and localities, while associations with Podozamites lanceolatus (= Podozamites distans in this flora; P. lanceolatus was a misidentification) and Pachypteris rhomboidalis (EtTingshausen) Doludenko, 1974 are the exception..

\section{Remarks on spore morphology}

So far, all fossil schizaeaceous species described from Triassic and Jurassic strata have ornamented, mainly reticulate spores (e.g. Stachypteris spicans), just as in species of the extant subgenus Odontopteris (Van Konijnenburg-van Cittert 1991). Spores of the subgenera Gisopteris and Lygodium s. str. have much less ornamented, smooth to scabrate spores (Van Konijnenburg-van Cittert 1991). Phialopteris spores have the same ornamentation type as the latter, and this record is by far the earliest of a fossil similar to Lygodium with this spore type. Manchester and Zavada (1987) described similar in situ spores from Eocene Lygodium kaulfussii HeER, 1861 from Wyoming, USA, and Gandolfo et al. (2000) described L. bierhorstiana GANDOLFo et al., 2000 from the Turonian (Late Cretaceous) of New Jersey, USA. The latter stated that those two fossil species together with the Australian Tertiary species L. dinmorphyllum CHURCHILL, 1969 form a clade with extant Lygodium (Gandolfo et al. 2000).

Spores morphologically similar to the here-described in situ spores were also recorded from the Rhaetian - Hettangian of Franconia. Triangular to slightly roundish spores, a distinct trilete mark and a generally smooth exospore that can be punctate or slightly granulate in the area between the rays of the trilete mark were assigned by Achilles (1981) to Cyathidites australis COUPER, 1953. These were abundant both in the Rhaetian and "Liassic" of Franconia, including in the "Lias $\alpha 1$ und $\alpha 2$ " of Forkendorf (= Hettangian) (Achilles 1981). Cyathidites COUPER, 1953 is generally assigned to the ferns with a possible botanical affinity with Cyatheaceae/Dicksoniaceae/Schizaeaceae although it was most closely related to Cyathea (e.g. Bowman et al. 2014). Couper (1958) and Van Konijnenburg-van Cittert (1989) found 
another species of this genus, Cyathidites minor COUPER, 1953 in situ in cyatheaceous and dicksoniaceous ferns. The general leaf shape and reproductive organ would, however, exclude an attribution to the latter families for Phialopteris heterophylla, supporting rather an affinity with Schizaeaceae. This would indicate that the dispersed-spore-species Cycathidites australis could also belong to the Schizaeaceae.

\section{Acknowledgements}

We are very grateful to Gea Zijlstra for her help with the nomenclatorial issues. Thanks are also due to Fabian Ercan for his help with the LM spore photos, and Jan van Tongeren for the SEM photos.

\section{References}

Achilles, H. (1981): Die rätische und liassische Mikroflora Frankens. - Palaeontographica, Abt. B, 179: 1-86.

Axsmith, B. J. (2009): A new Cynepteris from the Upper Triassic of Arizona: potential implications for the early diversification of schizaealean ferns. - International Journal of Plant Sciences, 170(5): 657-665. https://doi.org/10.1086/597782

Bowman, V. C., Francis, J. E., Askin, R. A., Riding, J. B., Swindles, G. T. (2014): Latest Cretaceous - earliest Paleogene vegetation and climate change at the high southern latitudes: palynological evidence from Seymour Island, Antarctic Peninsula. - Palaeogeography, Palaeoclimatology, Palaeoecology, 408: 26-47. https://doi.org/10.1016/j.palaeo.2014.04.018

Couper, R. A. (1958): British Mesozoic microspores and pollen grains. A systematic and stratigraphic study. Palaeontographica, Abt. B, 103: 75-179.

Christenhusz, M. J. M., Zhang, X.-C., Schneider, H. (2011): A linear sequence of extant families and genera of lycophytes and ferns. - Phytotaxa, 19: 7-54. https://doi.org/10.11646/phytotaxa.19.1.2

De la Sota, E. R., Morbelli, M. A. (1987): Schizaeales. Phytomorphology, 37: 365-393.

Doludenko, M. P. (1974): On the relation of the genera Pachypteris, Thinnfeldia and Cycadopteris. - In: Symposium on Morphological and Stratigraphical Palaeobotany. Special Publication, Birbal Sahni Institute of Palaeobotany, 2: 8-16.

Freudenberger, W. et al. (1994): Geologische Übersichtskarte 1:200 000, Blatt CC6326 Bamberg. - Bundesanstalt für Geowissenschaften und Rohstoffkunde in Zusammenarbeit mit dem Bayerischen Geologischen Landesamt, 1 p. (map).

Gandolfo, M. A., Nixon, K. C., Crepet, W. L., Ratcliffe, G. E. (2000): Sorophores of Lygodium Sw. (Schizaeaceae) from the Late Cretaceous of New Jersey. - Plant Systematics and Evolution, 221: 113-123. https://doi.org/10.1007/BF01086385

Göppert, H. R. (1836): Die fossilen Farnkräuter. - Verhandlungen der kaiserlichen Leopoldinisch-Carolinischen Akademie der Naturforscher, Band 17 supplement, 488 pp.

Göppert, H. R. (1841): Die Gattungen der fossilen Pflanzen. - Verlag von Henry und Cohen, Bonn, non-paginated.
Gothan, W. (1914): Die unterliassische (rhätische) Flora der Umgegend von Nürnberg. - Abhandlungen Naturhistorischen Gesellschaft Nürnberg, 19: 89-186.

Harris, T. M. (1961): The Yorkshire Jurassic Flora I. Thallophyta - Pteridophyta. - British Museum (Natural History), London, 212 pp.

Jung, W., Knobloch, E. (1972): Die „STERNBERG-Originale" der Bayerischen Staatssammlung für Paläontologie und historische Geologie zu München. - Mitteilungen der Bayerischen Staatssammlung für Paläontologie und historische Geologie, 12: 105-111.

Kräusel, R. (1958): Die Juraflora von Sassendorf bei Bamberg. I. Sporenpflanzen. - Senckenbergiana lethaea, 39: 67-103.

Krings, M., Kerp, H. (1999): Morphology, growth habit, and ecology of Blanzyopteris praedentata (Gothan) nov. comb., a climbing neuropteroid seed fern from the Stephanian of central France. - International Journal of Plant Sciences 160: 603-619.

https://doi.org/10.1086/314154

Kvaček, J., Straková, M. (1997): Catalogue of fossil plants described in works of Kaspar M. Sternberg. - National Museum Prague, Prague, 201 pp.

Manchester, S. R., Zavada, M. S. (1987): Lygodium foliage with intact sorophores from the Eocene of Wyoming. Botanical Gazette, 48(3): 392-399. https://doi.org/10.1086/337668

McNeill, J., Barrie, F. R., Buck, W. R., Demoulin, V., Greuter, W., Hawksworth, D. L., Herendeen, P. S., Knapp, S., Marhold, K., Prado, J., Prud'homme van Reine, W. F., Smith, G. F., Wiersema, J. H., Turland, N. J. (2012): International Code of Nomenclature for algae, fungi, and plants (Melbourne Code) (Regnum Vegetabile, vol. 154). - Koeltz Scientific Books, Königstein, xxx + 240 pp.

Ociepa, A. M., Barbacka, M. (2011): Spesia antarctica gen. et sp. nov. - a new fertile fern spike from the Jurassic of Antarctica. - Polish Polar Research, 32: 59-66. https://doi.org/10.2478/v10183-011-0007-7

Pomel, A. (1849): Matériaux pour servir à la flore fossile des terrains jurassiques de la France. - Amtliche Berichte und Versammlungen der Gesellschaft Deutscher Naturforscher und Ärzte, 25: 332-354.

Pott, C., Bouchal, J. M., Choo, T. Y. S., Yousif, R., Bomfleur, B. (2018). Ferns and fern allies from the Carnian (Upper Triassic) of Lunz am See, Lower Austria: A melting pot of Mesozoic fern vegetation. - Palaeontographica, Abt. B, 297: 1-101.

Rozefelds, A. C., Dettmann, M. E., Trevor Clifford, H., Carpenter, R. J. (2017): Lygodium in southern high latitudes during the Cenozoic - A new species and new insights into character evolution in the genus. - Review of Palaeobotany and Palynology, 247: 40-52. https://doi.org/10.1016/j.revpalbo.2017.07.001

Schenk, A. (1864): Beiträge zur Flora des Keupers und der rhätischen Formation. - Berichte der Naturforschenden Gesellschaft zu Bamberg, 7: 51-142.

Schenk, A. (1865-1867): Die fossile Flora der Grenzschichten des Keupers und Lias Frankens. - Kreidel, Wiesbaden, $232 \mathrm{pp}$. 
Sternberg, K. M. von (1838): Versuch einer geognostischbotanischen Darstellung der Flora der Vorwelt, Vol. II, 7. and 8. Heft. - Gotlieb Hässe Söhne, Prag, pp. 81-220.

Van Konijnenburg-van Cittert, J. H. A. (1989): Dicksoniaceous spores in situ from the Jurassic of Yorkshire, England. - Review of Palaeobotany and Palynology, 61(3-4): 273-301. https://doi.org/10.1016/0034-6667(89)90035-3

Van Konijnenburg-van Cittert, J. H. A. (1991): Diversification of spores in fossil and extant Schizaeaceae. - In: Blackmore, S., Barnes, H. (eds), Pollen and Spores, Patterns of Diversification. Systematics Association Special Volume Series, 44: 103-118.

Van Konijnenburg-van Cittert, J. H. A. (1992): The evolutionary development of Schizaeaceous spores in situ. Courier Forschungs-Institut Senckenberg, 147: 109-117.

Weber, R. (1968): Die fossile Flora der Rhät-Lias-Übergangsschichten von Bayreuth (Oberfranken) unter besonderer Berücksichtigung der Coenologie. - Erlanger geologische Abhandlungen, 72: 1-73.

\section{Explanations of plates}

\section{PLATE 1}

Phialopteris heterophylla (STERNBERG ex GÖPPERT) VAN Konijnenburg-van Cittert, Pott, Kustatscher, Schmeissner, DütSCH et VAN DER Burgh, comb. nov.

1. Largest sterile specimen showing the delicate nature of the frond (UU11933).

2. Detail from 1, showing morphology of the pinnae and pinnules and the faintly zig-zag-shaped rachis.

3. Partly sterile and partly fertile frond fragment (E15-91).

Scale bar: 1, 2- $10 \mathrm{~mm}, 3-5 \mathrm{~mm}$.

\section{PLATE 2}

Phialopteris heterophylla (STERNBERG ex GÖPPERT) VAN Konijnenburg-van Cittert, Pott, Kustatscher, Schmeissner, Dütsch et VAN DER Burgh, comb. nov.

1. Large fertile frond fragment, mainly consisting of fertile spikes; note the larger apical spikes (arrowheads) (UU11015).

2. Entirely fertile frond fragment showing the arrangement of mature spikes (sorophores), single sporangia indicated by black organic matter (23D02).

3. Partly fertile specimen showing the larger first acroscopic pinnules (30Kü16).

4. Part of an entirely fertile specimen with sporangia still preserved (exemplified by arrowheads) (24D02, counterpart of 2).

5. Entirely sterile specimen, showing zig-zag-shaped rachis and arrangement of pinnae and pinnules (37Kü16).

Scale bar: $10 \mathrm{~mm}$.

\section{PLATE 3}

Phialopteris heterophylla (STERnBERG ex GÖPPERT) VAN Konijnenburg-van Cittert, Pott, Kustatscher, Schmeissner, DüTSCH et VAN DER BURGH, comb. nov., frond portions and in situ spores (LM)

1. Hand specimen with a sterile frond fragment to the left and a fertile one to the right; the two are not organically connected but lay in the same bedding plane and may have been part of the same frond (E215-93).

2. Specimen with entirely fertile distal and apical ultimate pinnules (G1164-16).

3. 4. Single spores with faintly granulate perispore (D).

5. Group of spores.

Scale bar: 1, $2-10 \mathrm{~mm} ; 3,4-20 \mu \mathrm{m} ; 5-50 \mu \mathrm{m}$. 


\section{PLATE 1}

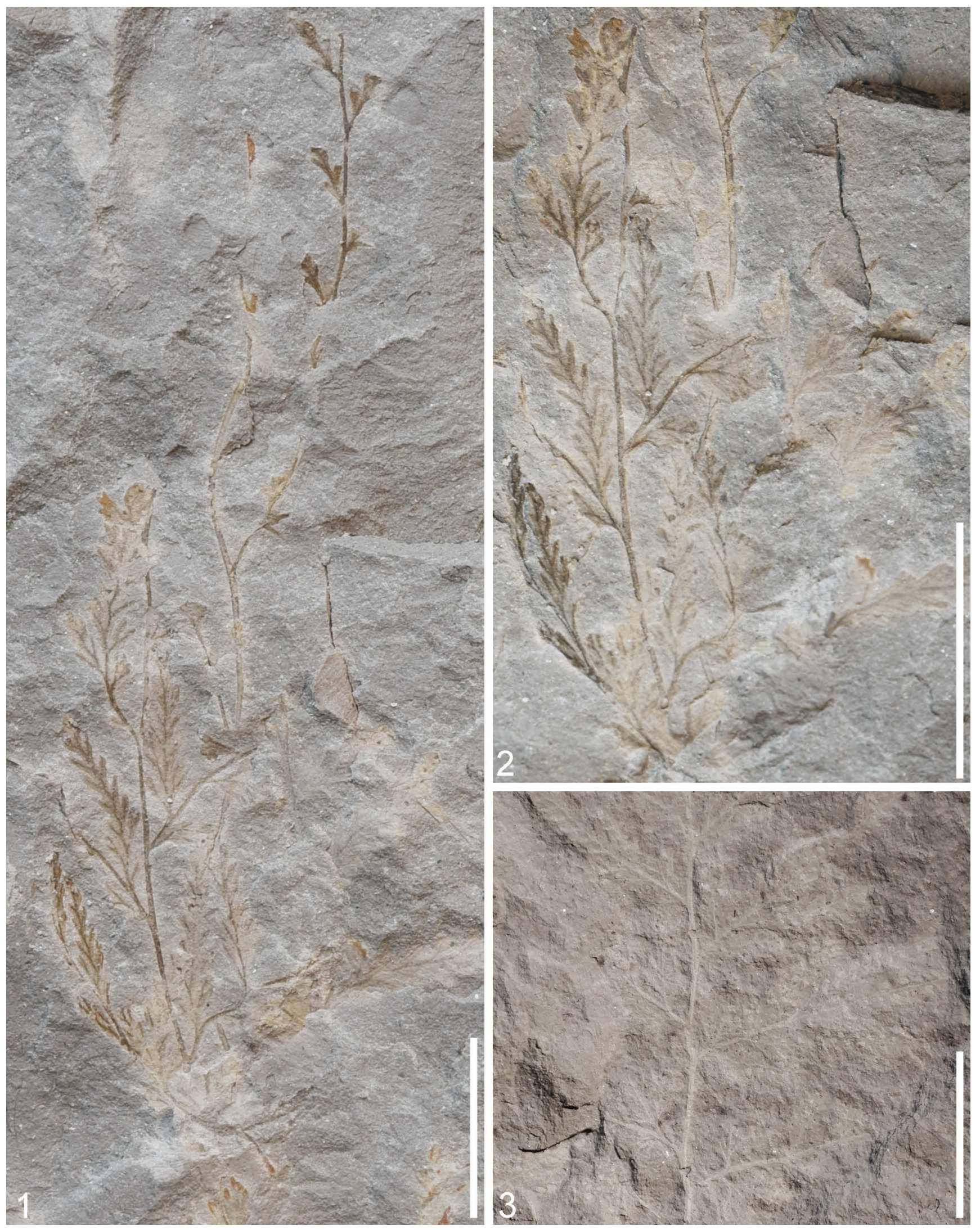




\section{PLATE 2}

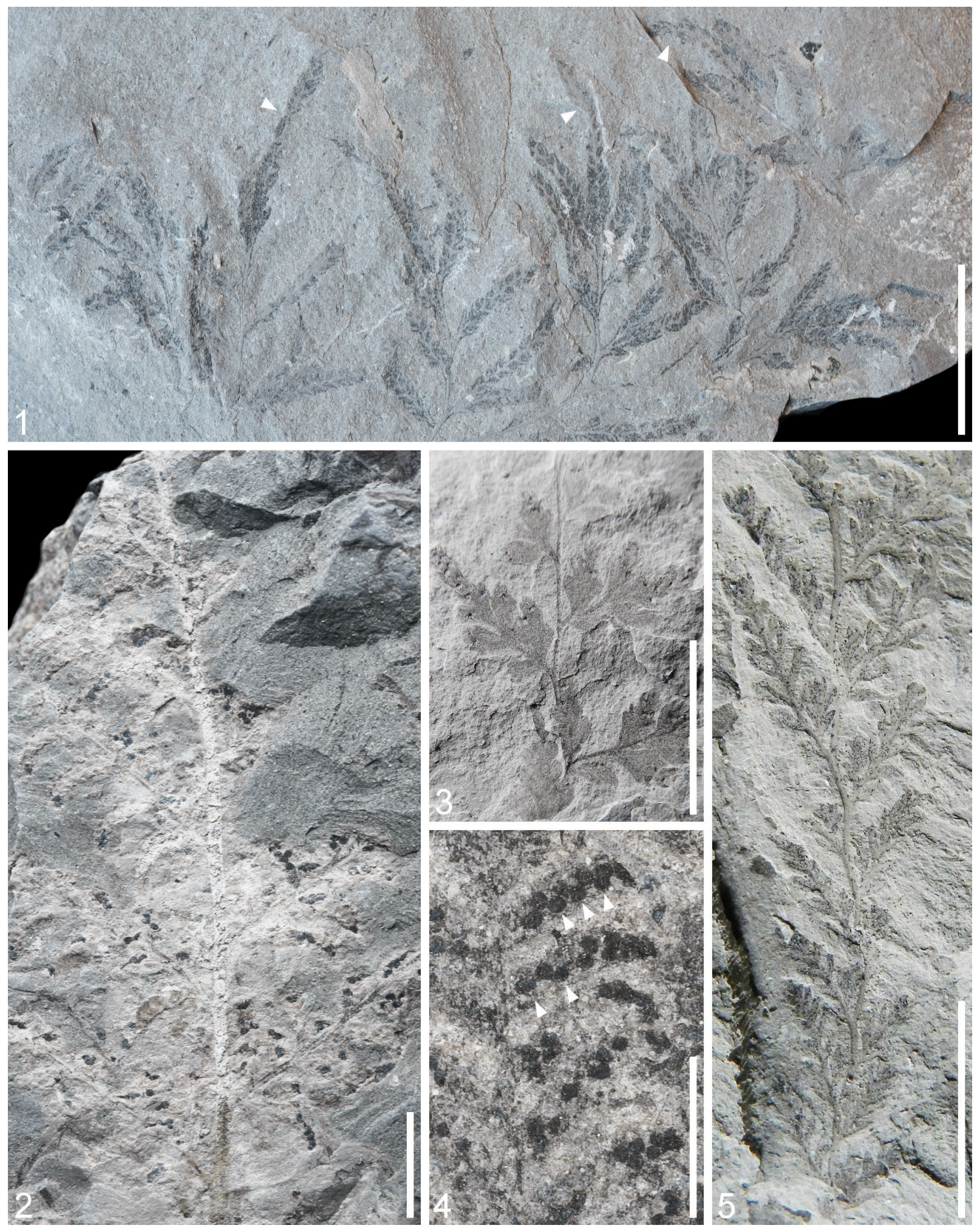




\section{PLATE 3}
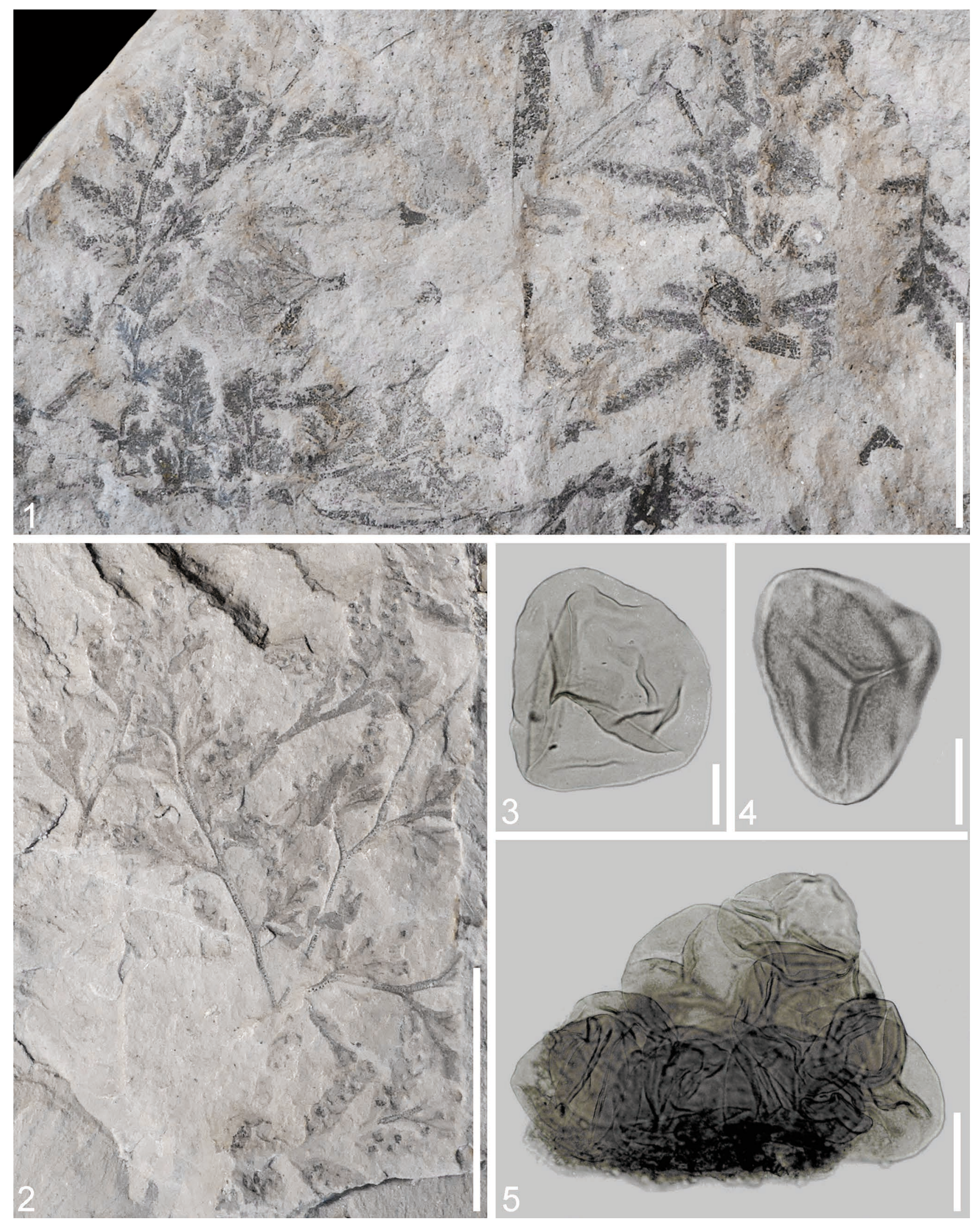